\title{
Correction to: History of Spinal Surgery and Surgical Treatment of Spinal Intradural Tumors
}

\author{
Bruno Splavski
}

\section{Correction to:}

Chapter 1 in: K. I. Arnautović, Z. L. Gokaslan (eds.), Spinal Cord Tumors, https://doi.org/10.1007/978-3-319-99438-3_1

This book was inadvertently published with interchanged figures 1.8 and 1.9. These figures has now been updated. 